高温瘦労破面の X 線フラクトグラフィ ${ }^{\dagger}$

小倉 敬 二* 三好良 夫* 川口真 広**

\title{
X-Ray Fractographic Study of Fatigue Fracture Surface at Elevated Temperatures
}

by

Keiji OGURA*, Yoshio Mryoshi* and Masahiro Kawaguchi**

An X-ray fractographic study was made on the fatigue fracture surface of HT80 and S53C steels at elevated temperatures up to $400^{\circ} \mathrm{C}$.

Emphasis was put on examing the effects of oxide film and fracture surface roughness on the residual stress and half-value breadth of fracture surface at elevated temperatures. It was found that the oxide film induced on the fracture surface at elevated temperatures was thin enough and was not detrimental for the application of X-ray fractography to analyze the fracture surface of steels up to $400^{\circ} \mathrm{C}$.

However, it was also found that the increased fracture roughness beyond a certain value was detrimental. The value was estimated as about $7.5 \mu \mathrm{m}$ in the center line average roughness. For this case, it is difficult to apply X-ray fractography because both the residual stress and half-value breadth are controlled not only by $K_{\max }$ or $\Delta K$ but also by the roughness of fracture surface.

キー・ワード：高温疲労破面, 残留応力, 半価幅, X線フラクトグラフィ

\section{1 緒言}

X線フラクトグラフィは破面上のみならず，破面下 の残留応力や半価幅などのX線的情報より破面解析が 可能である. そのためエレクトロンフラクトグラフィ では解析が困難である破壊後の時間経過により破面が 腐食, 酸化などの二次的損傷を受けている場合などの 破面解析にも有效な手段として研究が進められている。 しかし、これまでの研究の多くは, 著者らの研究も含 め, 室温, 大気中での疲労破面についての基礎的研究 であり，実用構造部材の破面解析にこの手法を応用す るためには, 二次的損傷のある場合のX線フラクトグ ラフィの適用の可否の検討が必要である。破面より得 られるX線的情報が使用する特性X線の波長や材料の 吸収率により定まるある深さまでの平均值であること

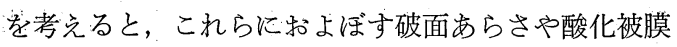
の影響を定量的に把握して括くこともまた同時に重要 そ考光られる.

そこで本研究では HT80 抢よび S53C 鋼を用い,
高温下の疲労破面につきX線フラクトグラフィの適用 の可否を検討すると同時に，破面上に形成された酸化 被膜や破面あらさが破面残留応力を中心とするX線情 報に与える影響について検討した.

\section{2 実 験 方 法}

本実験に用いた材料は Table I に示すような化学

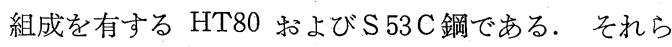
の室温, ならびに各試験温度下の機械的性質を Table IIに示した.これらの材料はいずれも供試のまま実験 に供した.

用いた試験片は, Fig. 1 に示す板厚 $10 \mathrm{~mm}$ の CT 試験片で，採取方向はいずれの場合も L-Tである.

疲労き裂進展試験はいずれの鋼, 試験温度とも種々 の応力比で, 通常の荷重振幅一定で行った。

X線による残留応力, 半価幅の測定については照射 域をいずれの鋼とも $1 \mathrm{~mm}$ (き裂進展方向) $\times 5 \mathrm{~mm}$ と した点が異なるのみで, 他の条件は前報と同様である ので，ここでは省略する。な拉，それらの值の算出は

Table I. Chemical composition of the materials used for experiment. (wt\%)

\begin{tabular}{|c|c|c|c|c|c|c|c|c|c|c|c|c|}
\hline Material & $\cdots C$ & $\mathrm{Si}$ & $\mathrm{Mn}$ & $\mathrm{P}$ & S & $\mathrm{A} 1$ & $\mathrm{Cu}$ & $\mathrm{Ni}$ & $\mathrm{Cr}$ & Mo & $\mathrm{V}$ & $\mathrm{Fe}$ \\
\hline $\mathrm{HT} 80$ & 0.11 & 0.24 & 0.83 & 0.010 & 0.003 & 0.050 & 0.19 & 0.98 & 0.49 & 0.45 & 0.035 & $\mathrm{R}$ \\
\hline S53C & 0.53 & 0.22 & 0.81 & 0.025 & 0.007 & 0.043 & 0.01 & 0.01 & 0.10 & - & - & $\mathrm{R}$ \\
\hline
\end{tabular}

†”原稿受理 昭和60年10月12日 Received Oct. 12, 1985

* 正会員 大阪大学基礎工学部 豊中市待兼山町, Faculty of Engineering Science, Osaka University, Machikaneyama-cho, Osaka

** 学生会員 大阪大学大学院 豊中市待廉山町, Graduate Student, Osaka University, Machikaneyama-cho, Osaka 
Table II. Mechanical properties of the materials used for experiment.

\begin{tabular}{c|c|c|c|c}
\hline \multirow{2}{*}{ Material } & $\begin{array}{c}\text { Tem- } \\
\text { perature } \\
T\left({ }^{\circ} \mathrm{C}\right)\end{array}$ & $\begin{array}{c}\text { Yield } \\
\text { strength } \\
\sigma_{\boldsymbol{y}}(\mathrm{MPa})\end{array}$ & $\begin{array}{c}\text { Tensile } \\
\text { strength } \\
\boldsymbol{\sigma}_{\boldsymbol{B}}(\mathrm{MPa})\end{array}$ & $\begin{array}{c}\text { Elongation } \\
(\%)\end{array}$ \\
\hline \multirow{3}{*}{ HT 80 } & r.t. & 803 & 862 & 23.0 \\
& 200 & 743 & 844 & 23.0 \\
& 300 & 719 & 846 & 24.0 \\
& 400 & 729 & 848 & 22.2 \\
\hline \multirow{3}{*}{ S53C } & r.t. & 439 & 751 & 14.4 \\
& 300 & 425 & 808 & 20.7 \\
\hline
\end{tabular}

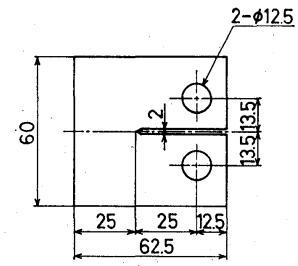

Fig. 1. Shape and dimensions of the specimens used for experiment. ( $t=10 \mathrm{~mm})$

ディフラクトメータに $\mathrm{A} / \mathrm{D}$ 変換器 とパソコンを接続 し，パソコンに取り达んだ回折強度曲線を自動解析す ることにより行った.

また，破面上の残留応力に対する破面あらさの影響 を定量的に評価するために，触針式あらさ計にA/D 変換器とパソコンを接続し，それらよりき裂進展方向 の破面あらさを測定するとともにその様相の三次元表 示をも行った.

\section{3 実験結果および考察}

\section{$3 \cdot 1$ 高温疲労破面上の回折強度曲線}

高温下の疲労破壊に扣いてはその破面上に $\mathrm{Fe}_{2} \mathrm{O}_{3}$ や $\mathrm{Fe}_{3} \mathrm{O}_{4}$ といった酸化被膜が形成される. その被膜 によるX線の吸収のため母相からの十分な回折強度が 得られなかったり，またピーク位置が，シフトするこ となどが考光られる，そこで，残留応力測定に先立ち 室温, 高温下の疲労破面の, $\psi_{0}=0^{\circ}$ に打忊回折強 度曲線の比較を行った. Fig. 2 (a)，(b)はその結果であ るが，いずれの鋼とも $300^{\circ} \mathrm{C}$ の回折強度は室温のもの と比べて若干低下しているが, 残留応力の測定精度に 影響を与えるほどの強度の低下は認められない。

\section{$3 \cdot 2$ 破面残留応力に対する試験温度の影響}

Fig. 3 は HT 80 鋼の疲労破面上の残留応力 $\sigma_{r}$ と $K_{\max }$ 関係に対する試験温度の影響を調べた結果であ る. ここでは応力比を $R=0.5$ と一定にして, 試験温 度を $200^{\circ} \mathrm{C}, 300^{\circ} \mathrm{C}, 400{ }^{\circ} \mathrm{C}$ 変化させた.な找，比較 のため室温の結果も同時に示した. Fig. 3 において高 温下の $\sigma_{r}$ は, 室温と同様に, 低 $K_{\max }$ 域でほぼ一定 值を示した後, $K_{\max }$ とともに減少する. 同一 $K_{\max }$

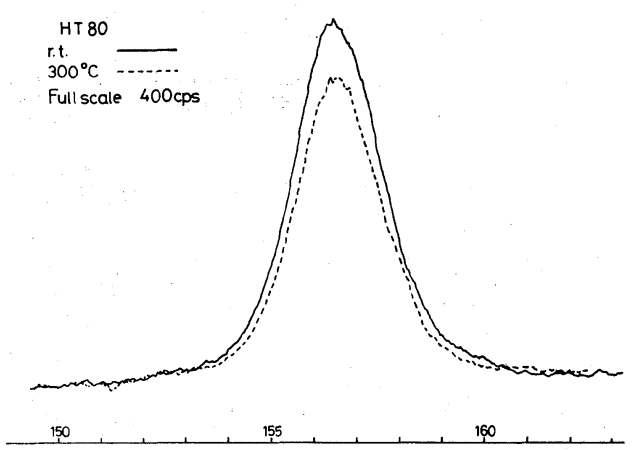

(a) HT80 steel

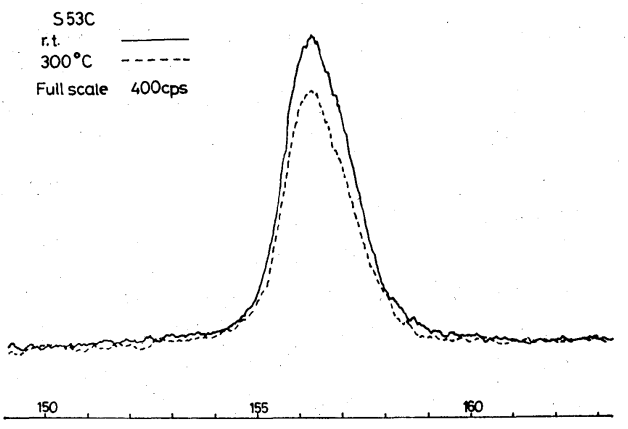

(b) $\mathrm{S} 53 \mathrm{C}$ steel

Fig. 2. X-ray diffraction curves from the fracture surface.

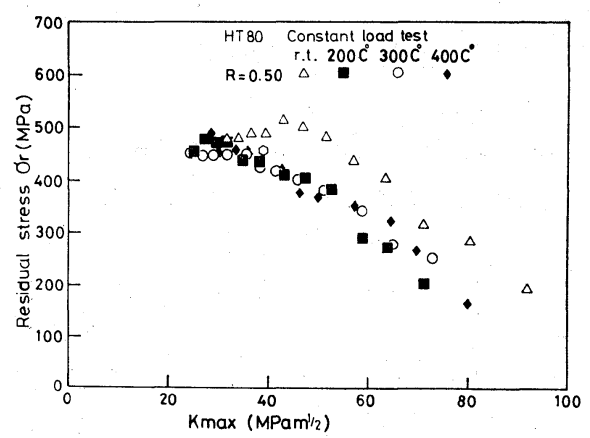

Fig. 3. The effect of test temperature on the relation between $\sigma_{r}$ and $K_{\max }$.

值に和ける $\sigma_{r}$ の值は，200〜 400 $\mathrm{C}$ の間ではほとんど 差がなくほぼ同じ值を示しているが室温下のものと比 べてみるとやや小さくなっている. また，これらの試 験温度間での $\sigma_{r}$ に差はなくほぼ同じ值を示している. これらの傾向は, Table II からもわかるように, HT 80 鋼の降伏応力の温度依存に良く対応している. 高温 に拈ける $\sigma_{r}$ の低下は高温保持によるひずみ取りなど の効果により解放されたものではなく，降伏応力の低 下に対応しているものと考光られる.

以上の結果から $400^{\circ} \mathrm{C}$ に至る高温破面でも比較的酸 化被膜が薄い場合には，X線による破面解析が十分可 能であることが明らかとなった. そこで，つぎに各鋼 の試験温度 $300^{\circ} \mathrm{C} て ゙$ 応力比を変化させて得た各鋼の疲 
労破面につきその残留応力 $\sigma_{r}$ と応力拡大係数の最大 值 $K_{\max }$ の関係について検討した.

\section{$3 \cdot 3$ 破面上の残留応力分布}

Fig. 4 は HT80 鋼の $300^{\circ} \mathrm{C}$ 下で得た疲労き裂進展破 面上のき裂進展方向の残留応力 $\sigma_{r}$ を破面形成時の応 力拡大係数の最大值 $K_{\max }$ で整理したものである。な 抒，図中には比較のために室温下の結果も同時に示し た. Fig. 4 に执いて $300^{\circ} \mathrm{C}$ 下の疲労破面上の残留応力 $\sigma_{r}$ は室温下と同様に引張 りであるが，同一応力比， 同一 $K_{\max }$ 值に括ける $\sigma_{r}$ 值は室温下のものに比べて 小さくなっている.さらに，高温下の $K_{\max }$ に対する $\sigma_{r}$ の変化には室温下 のそれとかなり異なる 傾向が認 められる．すなわち室温下の $\sigma_{r}$ は低 $K_{\max }$ 域では応 力比に依存せず $K_{\max }$ とともに增大し， $K_{\max }$ が約 30 $\mathrm{MPa} \sqrt{\mathrm{m}}$ 付近で最大值を示した後単調に減少してい る. 高 $K_{\max }$ 域では, 顕著な応力比依存性を示す. そ

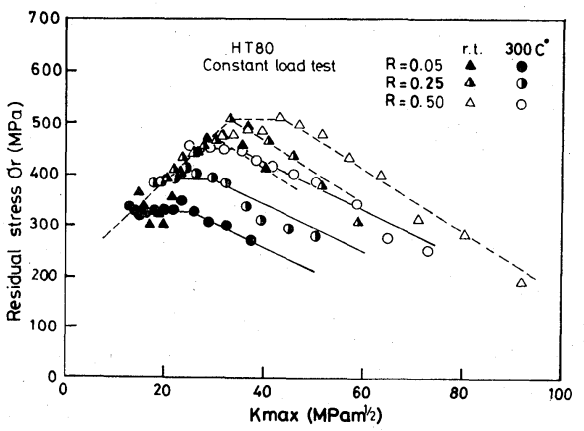

Fig. 4. The relation between the residual stress on fracture surface of HT80 steel and the maximum stress intensity factor.

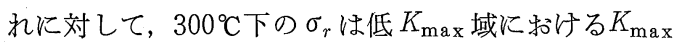
とともに增大する部分は注とえぞ認められず，泳ぼ一 定值を示した後，ある $K_{\max }$ 值から単調に減少する傾 向にある。 $\sigma_{r}$ が一定值をとる領域拉よび $K_{\max }$ とと もに減少する領域のいずれに打いても $\sigma_{r}$ 亿応力比依 存性が認められる. 後者の領域に和ける $\sigma_{r}$ の応力比 依存性性高温, 室温とも同一傾向（ $R$ の減少とともに $\sigma_{r}$ は減少）にはあるが 高温下ではその減少の度合い が非常に大きい，以上の上らな $300^{\circ} \mathrm{C} に$ 打ける $\sigma_{r^{-}}$ $K_{\max }$ の関係の室温下のそれとの相違は降伏応力の低 下に比例した $\sigma_{r}$ の低下といら直接的原因のみでは説 明し得ないように思われる。

一方，Fig. 5 は S 53 C 鋼につき，室温ならびに $300^{\circ} \mathrm{C}$ 下で得た疲労破面上の残留応力 $\sigma_{r}$ を $K_{\max }$ に対して プロットしたものである. S $53 \mathrm{C}$ 鋼に扮いても $\sigma_{r}$ の 絶対值は, HT80 鋼と同様に, 応力比, $K_{\max }$ が同じ であっても $300^{\circ} \mathrm{C}$ の方が室温下のものに比べて小さく なっている. しかし， $K_{\max }$ に対する $\sigma_{r}$ の変化挙動 には HT80 鋼のように 高温と室温で顕著な差は認め

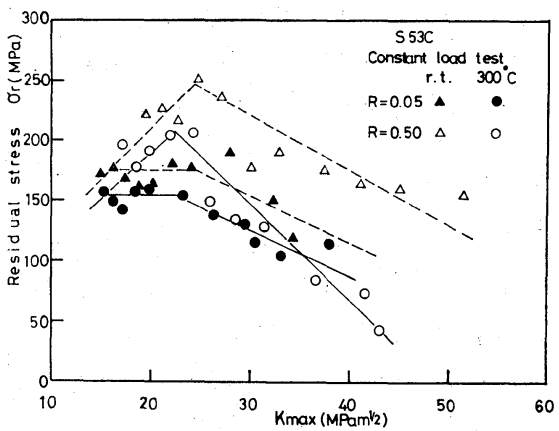

Fig. 5. The relation between the residual stress on fracture surface of S53C steel and the maximum stress intensity factor.

られないすすなわちいずれの温度においても $R=0.05$ そ扮いては $\sigma_{r}$ は， $K_{\max }$ が約 $25 \mathrm{MPa}_{V} \overline{\mathrm{m}}$ 付近まで 泳一定，その後，単調に減少，また $R=0.5$ 飞打い ては， $\sigma_{r}$ が $K_{\max }$ とともに增加 $K_{\max }$ が $20 \sim 25$ $\mathrm{MPa} \sqrt{\mathrm{m}}$ 付近で最大值を示した後減少に転じている. $R=0.5,300^{\circ} \mathrm{C}$ 下の $\sigma_{r}$ は $K_{\max }$ の大きい部分で特に 大きく減少している．このように S 53 C 鋼の $\sigma_{r}-K_{\max }$ 関係は HT80 鋼とは異なり試験温度依存性が小さい 傾向にある.

著者らは前報に扔いて室温下の疲労破面上の $\sigma_{r}$ が $K_{\max }$ に支配される $\sigma_{r 1}$ と $\Delta K$ に支配される。 $-\sigma_{r 2}$ の和として与兄ら，室温下のそれらの関係が，Fig. 6 (a)，(b)のように整理できることを示した。 ここで， $\left(K_{\max }\right)_{s}$ は $K_{\max }$ の增大に伴う一方向塑性ひずみの 增大に起因する残留応力 $\sigma_{r 1}$ が飽和するときの $K_{\max }$ 值であり，材料の降伏応力に低存する量である。すな わち降伏応力が高いるのでは単調塑性域寸法も小さく なるので，まわりからの弾性拘束が強く働くために $\left(K_{\max }\right)_{s}$ 值は大きくなる. $(\Delta K)_{0}$ は, $\Delta K$ の增大に伴 万逆力向塑性ひずみに起因する残留応力 $-\sigma_{r 2}$ の影響 が $\sigma_{r}$ に現れ始めるときの $\Delta K$ 值であり，これは繰返

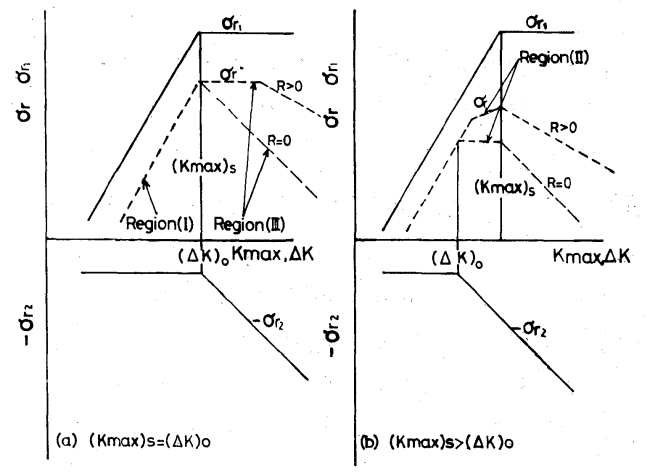

Fig. 6. Schematical illustration showing the effect of $K_{\max }$ or $\Delta K$ on the residual stress of the fracture surface. 
乙塑性域寸法と破面あらさの相対関係に依存する量で ある.したがって，応力比が異なっても破面あらさに 違いがなければ ( $(\Delta K)_{0}$ 值は材料固有のものとなり, $\sigma_{r 1}-K_{\max }$ 関係， $\sigma_{r 2}-\Delta K$ 関係は，材料により一意的に 定まる。

破面上の $\sigma_{r}$ と $K_{\max }$ の関係は $\left(K_{\max }\right)_{s}$ 值と $(\Delta K)_{0}$ 值の相対関係によって定るるものと考光られる。すな わち， $\left(K_{\max }\right)_{s}$ 值と $(\Delta K)_{0}$ 值がほぼ等しい場合の $\sigma_{r}-K_{\max }$ 関係は Fig. 6 (a)に破線で示したようになり， $R=0$ では領域 I， IIIが現れることになる．この関係 は本実験の HT80 鋼の室温下の結果に対応する. 一 方， $\left(K_{\max }\right)_{s}$ 值が $(\Delta K)_{0}$ 值に比べて大きい，い換 えれば $\sigma_{r}$ に $\Delta K$ の効果が早い時期に現れる場合には $\sigma_{r 1}$ の増大と $-\sigma_{r 2}$ の影響が互いに打ら消し合うため に, $\sigma_{r}-K_{\max }$ 関係は Fig. 6 (b)の破線のように $\sigma_{r}$ が $K_{\max }$ とともに単調に増加する領域 I， $K_{\max }$ によら ずほぼ一定值を示す領域II， $K_{\max }$ とともに単調に減 少する領域吕の三つの領域からなることになる。この 関係は本実験の $\mathrm{HT} 80$ 鋼の $300^{\circ} \mathrm{C}$ 下の結果に対応する。 これらのことから，HT80 鋼の $300^{\circ} \mathrm{C}$ 下の $\sigma_{r}-K_{\max }$ 関 係が Fig. 6 (b)のように現れたのは，300 C下のもので は, 室温下のものに比べて降伏応力の低下のために, $(\Delta K)_{0}$ 值が $\left(K_{\max }\right)_{s}$ 值に比べて相対的に小さくなっ たと考えると， $\sigma_{r}$ に対する $\Delta K$ の影響が低 $K_{\max }$ 域 から現れ始めることになるので， $\sigma_{r}-K_{\max }$ 関係むFig. 6 (b)のように領域 I， II， III が現れ実験結果と良く符 合する.

一方, $\mathrm{S} 53 \mathrm{C}$ 鋼では降伏応力は $300^{\circ} \mathrm{C} て ゙$ 室温とほと んぞ同じ值を示している. (Table II 参照) したがっ て， $\sigma_{r}-K_{\max }$ 関係も室温下と $300^{\circ} \mathrm{C}$ 下では差がないは ずである. 事実，Fig. 5 に見られるようにいずれの応 力比においても $\sigma_{r}-K_{\max }$ 関係は室温下と $300^{\circ} \mathrm{C}$ 下でよ く似た挙動を示している. しかし $\sigma_{r}$ の絶対值を比べ てみると，全体的に $300^{\circ} \mathrm{C}$ 下では室温に比べ低下して 打り， $R=0.5,300^{\circ} \mathrm{C}$ 下の条件のものは特に低下が激 しい.

筆者らは前報に括いて，破面上の残留応力 $\sigma_{r}$ の第 一支配因子は力学的因子であることを明らかにした。

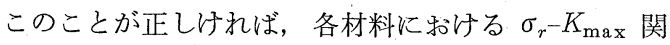
係はある適当な無次元化を行总ば材料，試験温度によ らず一つのマスターカーブ上に整理できるすのと考光 られる. そこで, 前報と同様に, Fig. 4, 5 の $\sigma_{r}-K_{\max }$ 関係から領域 I の結果を取り出し，それらを $K_{\max } に$ 対して整理した結果を Fig.7 (a)に，また，領域II， IIIの結果を取り出し，それらを $\Delta K$ で整理したものを Fig. 7 (b)に示した. ここで, HT80 鋼の結果ならびに 参考のために示した前報の SM50A, SNCM815 鋼の 室温疲労破面の結果はデータ点を省略してデータバン

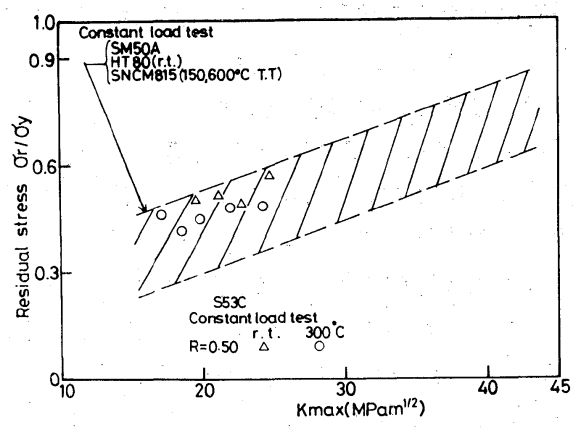

(a) Region I

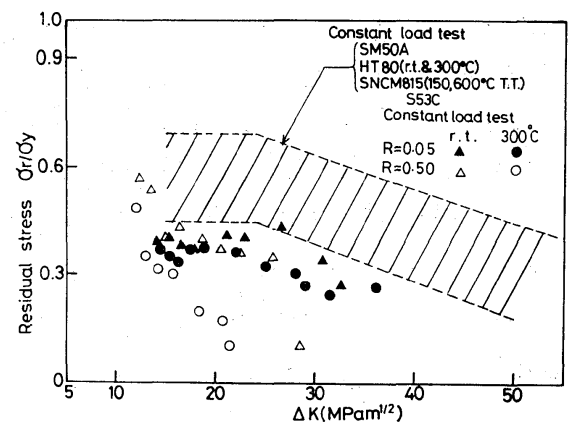

(b) Region II, II

Fig. 7. The dimensionless residual stress plotted against $K_{\max }$ or $\Delta K$.

ドで示した．な拉，これらの図で縦軸の $\sigma_{r}$ は各鋼の 試験温度に打ける降伏応力 $\sigma_{y}$ で無次元化した

Fig. 7 (a)，(b)飞抒いて，HT80 鋼の $\sigma_{r} / \sigma_{y}$ は室温， 高温下のいずれとも前報の室温下のデータバンド内に よく整理されている。しかしながら，S53C鋼では， $K_{\max }$ 支配域でのデータが，データバンド内に整理さ れるのに対して， $\Delta K$ 支配域のデータは Fig. 7 (b)の よらにデータバンドからはずれ，特に $R=0.5,300^{\circ} \mathrm{C}$ 下のものが大きくはずれて扮り， $\sigma_{r} / \sigma_{y}$ 值も全体的に 小さくなっている.

以上のことより, HT80 鋼の破面上の残留応力 $\sigma_{r}$ は前報の結果と同様, 室温・高温下ともに力学的因子 の支配度が高く，その変化挙動も Fig. 6 に示したよ うな力学モデルにより全体的に矛盾なく説明しらるよ

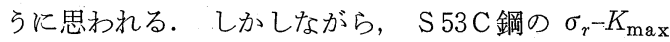
関係は HT80 鋼に対すると同様な考皇では十分説明 し得ないように思われる，力学因子の他の破面残留応 力の支配因子としては破面あらさの影響が考兄られる. そこで，つぎに破面のあらさ測定を行うとともに三次 元表示を行い破面の全体的な様相からも $\sigma_{r}-K_{\max }$. 関 係に対するあらさの影響の検討を行った。

$3 \cdot 4$ 破面上残留応力におよぼす破面あらさの影響

Fig. 8 は本実験で得た $\sigma_{r}-K_{\mathrm{max}}$ 関係で $\sigma_{r}$ が減少 あるいは一定值を示し始めるときの $K_{\max }$ 值 (Fig.7 の $\left.(\Delta K)_{0}\right)$ の近傍の破面中央部のあらさの様相を三次 


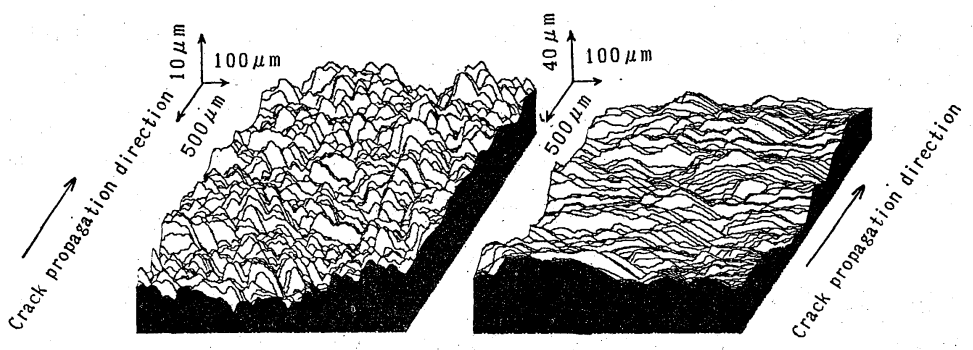

(a) HT.80 steel(room temperature)

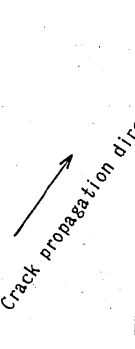

(b) $\mathrm{HT} 80$ steel $\left(300^{\circ} \mathrm{C}\right)$ $R=0.5, K \max =39.2 \mathrm{MPa} \sqrt{\mathrm{m}}$ $R=0.5, K \max =43.1 \mathrm{MPa} \sqrt{\mathrm{m}}$

(c) $\mathrm{S} 53 \mathrm{C}$ steel (room temperature)

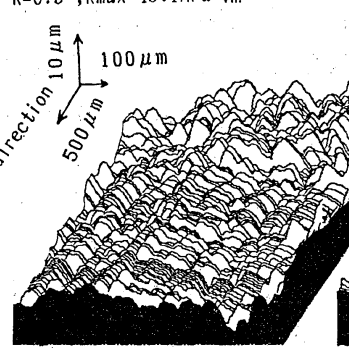

Fig. 8. Three dimensional picture of fatigue fracture surface.

元表示したものの一例である.

Fig. 8 (a)，(b)は HT80 鋼の室温ならびに $300^{\circ} \mathrm{C} の R$ $=0.5$ の破面あらさの様相であるが，いずれの破面と も山状の形態を示して敊り，全体的には両者に大差は 認められない. Fig. 8 (c), (d)は S 53 C 鋼の室温ならび に $300^{\circ} \mathrm{C}$ の $R=0.05$ の破面あらさの様相であるが，ら 㸚りを伴った大きな山より成って和り，あらさ自身も HT80 鋼に比べて大きくなっている. しかし, 室温, $300^{\circ} \mathrm{C}$ の両者では差は認められない。

以上は Fig. 4, 5 の $\sigma_{r}-K_{\max }$ 関係で $\Delta K$ 値が比較 的小さい $20 \mathrm{MPa}_{\sqrt{\mathrm{m}}}$ 付近のあらさの三次元表示によ り鋼種, 試験温度間の破面の形態やあらさを比較した が，つぎにいま少し，各測定点に和ける破面あらさを 定量的に評価する，得られた破面につき板厚中央部で の板厚方向の中心線平均あらさ $\mathrm{H}_{\mathrm{CLA}}$ （触針走査距離 $1 \mathrm{~mm}$ ）を測定し，それらと $\Delta K$ との関係を調べた.

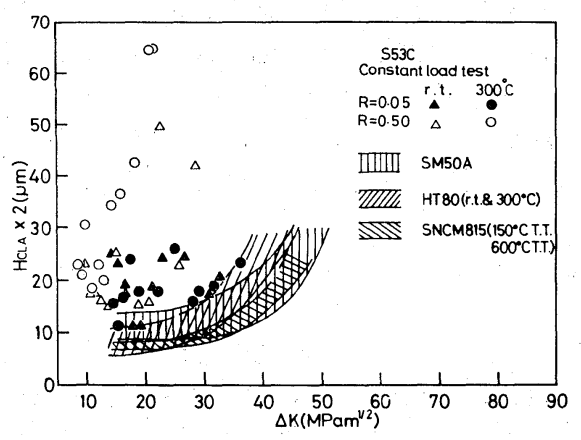

Fig. 9. The center line average roughness plotted against the stress intensity factor range.
Fig. 9 はその結果である.ここ で, HT 80 鋼の結果は比較の ために示した前報の SM $50 \mathrm{~A}$, SNCM815 鋼の室温破面の結果 と同様にデータ点を省略してデ ータバンドで示した. Fig. 9 よ りわかるよらに HT 80 鋼の破 面屴らさは応力比，試験温度に よらず低 $\Delta K$ 域で泳汸一定值を 示した後, $\Delta K$ とともに増大す る傾向にある， S 53 C 鋼の破面 あらさも $\Delta K$ とともに増大する 傾向にあるがその変化は HT80 鋼と異なり，応力比や試験温度 依存性が認められる。.また，特 飞 $300^{\circ} \mathrm{C}, R=0.5$ 飞打将る破 面あらさの増大が顕著に認めら れる. 3.3節で, $\sigma_{r}-K_{\max }$ の関 係が $\left(K_{\max }\right)_{s}$ と $\left.(\Delta K)_{0}\right)$ との相 対関係によって支配され，特に $(\Delta K)_{0}$ 值にあらさの影響が現れることを指摘した: しかし，本実験の HT 80 鋼の破面めらさやその様相 には試験温度や応力比による差は認められなかった。 それにもかかわらず，Fig. 4 に示すように $\sigma_{r}-K_{\max }$ 関係は試験温度による差異が認められたのは，その差 異が破面あらさによるものではなく，前述したように 高温下では降伏応力が低下するので繰返し塑性域寸法 が増大し $(\Delta K)_{0}$ 值が室温のものに比べて減少した結 果, 高温下の $\sigma_{r}-K_{\max }$ 関係洕領域 I, II, III が現れ たものと思われる. 一方, S 53 C 鋼では, Table II 飞 示したように高温下でも降伏応力は室温と同じであり， 応力比が同じで交れば室温，高温で $\sigma_{r}-K_{\max }$ 関係は 変らないはずであるが，Fig. 5 より明らかなよらにR $=0.5$ のものでは, 室温下と高温下で $\sigma_{r}$ の $K_{\max }$ に 対する減少率に差が認められた. 破面残留応力に対す る破面あらさの影響は乞の值を減少させる効果として 作用すると考兄られるのでこの結果はそれに対応する ものと思われる，その他の試験条件のものでも，破面 あらさの影響が現れ，破面あらさが大きい $\Delta K$ 域でデ ータバンドからはずれ $\sigma_{r}$ は小さくなっている. S 53 $\mathrm{C}$ 鋼の破面上の残留応力は, $\mathrm{HT} 80$ 鋼とは異なり, 力 学的因子に支配されているといらより怯むし破面が あらいために力学的因子に加光て, 破面あらさの影響 が，かなり強く現れていると考觉るのが妥当なようで ある、な拉，破面上の残留応力に破面あらさの影響が 現れ始めるときの破面あらさは， $\mathrm{H}_{\mathrm{CLA}} \times 2$ の值で括 よそ $15 \mu \mathrm{m}$ 程度と考光られる。

以上の結果から，HT80 鋼では高温疲労破面に抒い 
ても室温下のものと同様, X線による破面解析が十分 可能であるが， S 53 C 鋼では破面あらさがあらいこと による残留応力の解放や測定精度の低下といった問題 があり，X線による破面解析が十分可能であるとは言 い難い。

\section{$3 \cdot 5$ 破面上の半価幅分布}

Fig. 10 (a)，(b)はそれぞれ HT80 鋼，S 53 C 鋼の高 温疲労き裂進展破面の破面上の半価幅 $B$ と $K_{\max }$ の関 係を示したものである. 図中には, 比較のために室温 下に和ける結果も同時に示したが，いずれる $\psi_{0}=0^{\circ}$ に和ける半価幅である.Fig.10（a)に見られるように $\mathrm{HT} 80$ 鋼の $B$ は, 各試験温度とも $K_{\max }$ とともに増大 して，ある $K_{\max }$ 值以上ではほぼ一定值を示す傾向に ある. 同一 $K_{\max }$ 值に和ける $B$ は応力比により差があ り，その小さいものほど，すなわち $\Delta K$ の大きいもの 核ど小さくなっている。これは $\Delta K$ の大きいものほど 繰返し荷重による格子の整合性の回復が大きいためと 考えられる.また，同一 $K_{\max }$ で応力比が同じであっ てもBには室温と $300^{\circ} \mathrm{C}$ で差があり，高温下の方が $B$ は大きくなっている.一般には破面形成後も破面は加 熱保持されていることから室温に比較して半価幅は減 少するるのと思われる. しかし, 高温下では降伏応力 が減少するために単調負荷荷重による $B$ も増大するが, 繰返乙負荷荷重による $B$ の減少量も増大するので, HT80 鋼の場合には前者の增大量の方が後者のそれに

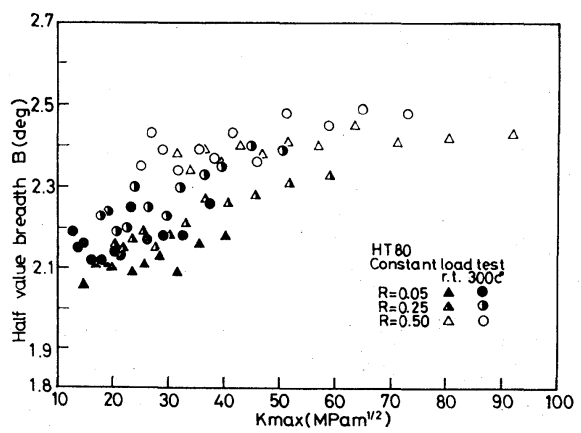

(a) HT80 steel

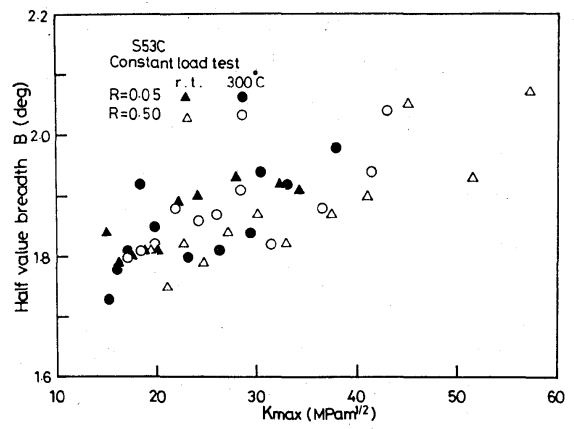

(b) $\mathrm{S53 \textrm {C }}$ steel

Fig. 10. Half-value breadth plotted aginst the maximum stress intensity factor.
比べて大きかったためと考光られる，な拉，半価幅の 変化に対しては破面あらさの影響も大きいと思われる が, HT80 鋼に和ける破面あらさはFig. 9 からもわか るよらに試験温度, 応力比によらず, 同じであることか ら，その影響はFig. 10 (a)飞は現れないものと思われる。 一方， S53C鋼のBは，Fig. 10 (b)に見られるよう に室温, $300^{\circ} \mathrm{C}$ と, $\mathrm{HT} 80$ 鋼と同様に $K_{\max }$ ととも に增大し, ある $K_{\max }$ 值以上ではほぼ一定值を示す傾 向にある.しかしながら，HT80 鋼に現れるような応 力比, 試験温度依存など系統的な挙動は認められない。 これは, S53C鋼では, 破面あらさの測定結果からも わかるように, 破面あらさがあらいために, その影響 が半価幅值に反映したためと考学られる。

\section{4 結 言}

$\mathrm{HT} 80$ 鋼, S $53 \mathrm{C}$ 鋼の高温疲労破面につき酸化被膜 や破面あらさがその破面上の残留応力に及洔す影響を 調べるとともに室温下の結果との比較検討を行った. 得られた結果を要約すると次のようである.

(1) HT80 鋼，S 53C 鋼とも高温下での破面に形成 される酸化被膜は薄く, その存在がX線情報を得るの にほとんど悪影響を及洔さないことが明らかとなった。

(2) HT80 鋼の高温下 $\left(300^{\circ} \mathrm{C}\right)$ 飞郝沙る破面上の 残留応力 $\sigma_{r}$ と $K_{\max }$ の関係と室温下のものとに差が 認められた，その差異は降伏応力の低下による $\sigma_{r}$ の 減少扣よび繰返し塑性域寸法の増大による $(\Delta K)_{0}$ 值 の減少によるものと考觉るとこれまでに提案したモデ ルにより挙動が説明できた。このことは高温下に括い ても破面残留応力の第一支配因子が力学因子であるこ とを示すものと思われ同時にX線フラクトグラフィの 適用の可能性を示寸るのと考兄られる.

(3) $\mathrm{S} 53 \mathrm{C}$ 鋼の室温ならびに 高温下 $\left(300^{\circ} \mathrm{C}\right)$ の 破 面上の残留応力 $\sigma_{r}$ は, HT80 鋼とは異なり, 破面あ らさがあらいため，力学的なものに加觉て破面あらさ の影響がかなり大きいことが明らかとなった。

以上のことより高温疲労破面であっても，X線フラ クトグラフィの適用は十分可能であるが，破面あらさ が $\mathrm{H}_{\mathrm{CLA}} \times 2$ の值で $15 \mu \mathrm{m}$ を超えるようなあらい場合 に打いては測定された残留応力値と力学量との対応関 係についての検討が今後さらに必要と思われる.

本研究を遂行するにあたり, 加留義夫〔現住友電工 (株)], 山口智久 [大阪大学学生]の両君には卒業研 究として助力を得た.

（昭和60年 7 月 18 日 第22回X線材料强度に関するシンポジウムにて講 演）

\section{参 考 文 献}

1）例之ば，田中啓介，畑中伸夫，材料， 31，215 (1982).

2）小倉敬二, 三好良夫, 鹿山昌宏, 昌子洋一, 材料, 33, 398 (1984).

3）小倉敬三, 三好良夫, 川口真広, 鹿山昌宏, 日本機械学 会論文集，A-51，1477 (1985). 